\title{
S1PR5 Gene
}

National Cancer Institute

\section{Source}

National Cancer Institute. S1PR5 Gene. NCI Thesaurus. Code C104782.

This gene plays a role in regulating cell proliferation, apoptosis, motility, and neurite retraction. 